\title{
Levels of Selected Heavy Metals in Food Packaging Papers and Paperboards Used in India
}

\author{
Swati Sood, Chhaya Sharma* \\ Environmental Research Laboratory, Department of Paper Technology, Indian Institute of Technology Roorkee, Saharanpur \\ Campus, Saharanpur, India \\ Email: *chhaya1964@rediffmail.com
}

How to cite this paper: Sood, S. and Sharma, C. (2019) Levels of Selected Heavy Metals in Food Packaging Papers and Paperboards Used in India. Journal of Environmental Protection, 10, 360-368. https://doi.org/10.4236/jep.2019.103021

Received: February 7, 2019

Accepted: March 5, 2019

Published: March 8, 2019

Copyright (อ 2019 by author(s) and Scientific Research Publishing Inc. This work is licensed under the Creative Commons Attribution International License (CC BY 4.0).

http://creativecommons.org/licenses/by/4.0/ (c) (i) Open Access

\begin{abstract}
In the present study, the varieties of papers and paperboards (PPBs) used in India for food packaging were qualitatively and quantitatively analyzed for the heavy metal contamination with the help of ICP-OES (Inductively Coupled Plasma-Optical Emission Spectrometry). Total 10 different types of food packaging $\mathrm{PPBs}$ were procured from local market and analyzed for 14 heavy metals ( $\mathrm{Al}, \mathrm{As}, \mathrm{B}, \mathrm{Ba}, \mathrm{Co}, \mathrm{Cr}, \mathrm{Cu}, \mathrm{Fe}, \mathrm{Mn}, \mathrm{Ni}, \mathrm{Pb}, \mathrm{Te}$, Ti and V). Quantities of heavy metals in the samples were compared with permitted values published by the European Council. Heavy metals like Al, As, Ba, Cr, Co, Ni, Pb and V were observed in more than the permitted concentration in some of the samples. Heavy metals toxicity in food packaging material is a serious concern as the edible items get exposed to these metals and also generate volatile odorous compounds which considerably impact the quality of food and affect consumer's health.
\end{abstract}

\section{Keywords}

Heavy Metals, Odorous Compounds, Food Packages,

Papers and Paperboards (PPBs), Health

\section{Introduction}

Food packaging PPBs are the most widely used source of food packaging all over the world [1]. Such abundant use of food packaging PPBs is promoted as they are inexpensive, light, and safe to use [2]. A lot of improvement in material as well as package design has led to the production of better and more food packaging PPBs [3]. However, some queries concerning the toxicological potential of these materials have been raised and this requires determining the standards of 
quality of raw material to be used for the production of food packaging PPBs [4]. The European Council Standard requires that various contaminants like aromatic amines, benzophenone, polyaromatic hydrocarbons, plasticizers and heavy metals are controlled and analyzed in food packages [5].

Heavy metals are a big source of environment pollution [6]. The toxicity of heavy metals has harmful effects on the biological systems as they do not undergo biodegradation, so they get accumulated in living beings causing many diseases and disorders even when present in very low concentration [7]. Heavy metals like chromium, cadmium, copper, zinc and nickel pollute the environment and strongly affect the human health [8]. Lead is found in paints, inks etc.; however most of the countries have prohibited its use in food packaging PPBs as it is deleterious to health [9]. The main function of food packaging PPBs is to protect and conserve the food's flavour. Sometimes, odorous compounds from the food packaging PPBs may get transferred to the food items and affect the food's flavour. This results in considerable losses and consumer dissatisfaction. The heavy metals like iron, copper, manganese and nickel are catalytically active even at very low concentration levels and are involved in the generation of odor in food packaging PPBs [10].

Although studies have focused on assessing the heavy metal levels in food packaging, but there is no information available on the content of heavy metals in Indian food packaging PPBs. The interest of present work lies in qualitative and quantitative monitoring of heavy metal levels in locally procured food packaging PPBs.

\section{Materials and Methods}

In this study the samples of total 10 food packaging PPBs have been collected from local markets. The study of analysis of heavy metals was conducted to keeping the heath concern in mind. 10 food PPBs which are used for direct food packaging were purchased from different confectionary stores situated in different parts of the city. In additional testing, 3 samples of each group of food packaging PPBs were purchased from the local retail outlets. The samples included paper plate, cake box, fruit tray, tissue paper, coffee cup, pastry box, sweet box, pizza box, French fries box, and paper bag. These food packaging paper are founds in frequently in the markets.

Closed vessel microwave system (Marsxpress; CEM, USA) was used for the digestion of samples. Operating conditions were followed as per the USEPA 3051 method. Digested solutions were cooled, filtered and diluted to $10 \mathrm{ml}$ with distilled water, prior to ICP-OES analysis. Multi-element standard (REICPCAL29A) was used to standardize and calibrate the metal concentration. Analytical reagents-grade chemicals and double distilled water were used for the preparation of solutions and dilutions respectively.

\section{Result and Discussion}

In the present study, 10 commercially available food packaging PPBs were 
checked for the presence of 14 heavy metals, which are generally present as residues of the recycling process and due to their presence in paper and pulp industry, so as to determine their suitability to be used as packaging materials which come in direct contact with foodstuffs.

Heavy metal content in 10 different types of locally procured food packaging $\mathrm{PPBs}$ is shown in Table 1. The level of heavy metals varied in the range; $\mathrm{Al}$ (11.7 - $102.7 \mathrm{ppm}), \mathrm{As}(\mathrm{Nd}-0.3 \mathrm{ppm}), \mathrm{B}(\mathrm{Nd}-0.03 \mathrm{ppm}), \mathrm{Ba}(0.26-1.1 \mathrm{ppm})$, Co (Nd - $0.05 \mathrm{ppm}), \mathrm{Cr}(0.02-2.1 \mathrm{ppm}), \mathrm{Cu}(0.04-0.8 \mathrm{ppm}), \mathrm{Fe}(0.4-37.2 \mathrm{ppm})$, $\mathrm{Mn}(\mathrm{Nd}-0.54 \mathrm{ppm}), \mathrm{Ni}(\mathrm{Nd}-0.19 \mathrm{ppm}), \mathrm{Pb}(\mathrm{Nd}-0.38 \mathrm{ppm}), \mathrm{Te}(\mathrm{Nd}-0.01$ $\mathrm{ppm}), \mathrm{Ti}(\mathrm{Nd}-0.15 \mathrm{ppm})$, and $\mathrm{V}(0.03-0.54 \mathrm{ppm})$. The highest concentration of $\mathrm{Al}, \mathrm{As}, \mathrm{Cu}, \mathrm{Fe}, \mathrm{Ni}$ and $\mathrm{V}$ were observed in Pizza box, while concentration of $\mathrm{Mn}, \mathrm{Pb}$ and $\mathrm{Te}$ were highest in Paper plate. Te was also present in highest amount in Fruit Tray. Pastry box had the highest concentration of Ba and Cr. B and Co were present in highest amount in French fries box and Coffee cup respectively. The maximum permitted quantity (ppm) as suggested by the Council of Europe for food packaging materials is Mn-1.8, Al-5, As-0.002, Ba-1.2,

Table 1. Concentrations (ppm) of 14 Heavy Metals detected in 10 Indian Food Packaging PPBs.

\begin{tabular}{|c|c|c|c|c|c|c|c|c|c|c|c|c|c|c|}
\hline $\begin{array}{l}\text { Heavy } \\
\text { metals } \\
\text { Sample }\end{array}$ & $\mathrm{Al}$ & As & B & $\mathrm{Ba}$ & Co & $\mathrm{Cr}$ & $\mathrm{Cu}$ & $\mathrm{Fe}$ & $\mathrm{Mn}$ & $\mathrm{Ni}$ & $\mathrm{Pb}$ & $\mathrm{Te}$ & $\mathrm{Ti}$ & $\mathrm{V}$ \\
\hline \multicolumn{15}{|l|}{ Permitted } \\
\hline $\begin{array}{l}\text { conc. } \\
\text { (ppm) }\end{array}$ & 5 & 0.002 & - & 1.2 & 0.02 & 0.250 & 4 & 40 & 1.8 & 0.14 & 0.010 & - & - & 0.01 \\
\hline $\begin{array}{l}\text { Paper } \\
\text { Plate }\end{array}$ & $\begin{array}{c}59.204 \pm \\
0.160\end{array}$ & $\begin{array}{c}0.109 \pm \\
0.012\end{array}$ & $\begin{array}{c}0.008 \pm \\
0.001\end{array}$ & $\begin{array}{c}0.687 \pm \\
0.001\end{array}$ & $\begin{array}{c}0.024 \pm \\
0.001\end{array}$ & $\begin{array}{c}0.602 \pm \\
0.008\end{array}$ & $\begin{array}{c}0.545 \pm \\
0.001\end{array}$ & $\begin{array}{c}15.919 \pm \\
0.036\end{array}$ & $\begin{array}{c}0.547 \pm \\
0.001\end{array}$ & $\begin{array}{c}0.089 \pm \\
0.005\end{array}$ & $\begin{array}{c}0.388 \pm \\
0.007\end{array}$ & $\begin{array}{c}0.012 \pm \\
0.005\end{array}$ & $\begin{array}{c}0.007 \pm \\
0.068\end{array}$ & $\begin{array}{c}0.373 \pm \\
0.001\end{array}$ \\
\hline Cake Box & $\begin{array}{c}32.063 \pm \\
0.035\end{array}$ & $\begin{array}{c}0.008 \pm \\
0.012\end{array}$ & $\begin{array}{c}0.012 \pm \\
0.000\end{array}$ & $\begin{array}{c}0.379 \pm \\
0.000\end{array}$ & $\mathrm{Nd}$ & $\begin{array}{c}0.159 \pm \\
0.007\end{array}$ & $\begin{array}{c}0.677 \pm \\
0.001\end{array}$ & $\begin{array}{c}11.847 \pm \\
0.012\end{array}$ & $\begin{array}{c}0.272 \pm \\
0.000\end{array}$ & $\begin{array}{c}0.027 \pm \\
0.004\end{array}$ & $\begin{array}{c}0.111 \pm \\
0.003\end{array}$ & $\begin{array}{c}0.011 \pm \\
0.008\end{array}$ & $\mathrm{Nd}$ & $\begin{array}{c}0.269 \pm \\
0.000\end{array}$ \\
\hline Fruit Tray & $\begin{array}{c}22.738 \pm \\
0.049\end{array}$ & $\mathrm{Nd}$ & $\mathrm{Nd}$ & $\begin{array}{c}0.284 \pm \\
0.000\end{array}$ & $\mathrm{Nd}$ & $\begin{array}{c}0.237 \pm \\
0.004\end{array}$ & $\begin{array}{c}0.790 \pm \\
0.000\end{array}$ & $\begin{array}{c}5.910 \pm \\
0.003\end{array}$ & $\begin{array}{c}0.322 \pm \\
0.000\end{array}$ & $\begin{array}{c}0.008 \pm \\
0.001\end{array}$ & $\begin{array}{c}0.112 \pm \\
0.005\end{array}$ & $\begin{array}{c}0.012 \pm \\
0.005\end{array}$ & $\mathrm{Nd}$ & $\begin{array}{c}0.127 \pm \\
0.000\end{array}$ \\
\hline $\begin{array}{l}\text { Tissue } \\
\text { Paper }\end{array}$ & $\begin{array}{c}11.763 \pm \\
0.018\end{array}$ & $\mathrm{Nd}$ & $\mathrm{Nd}$ & $\begin{array}{c}0.568 \pm \\
0.000\end{array}$ & $\mathrm{Nd}$ & $\begin{array}{c}0.118 \pm \\
0.001\end{array}$ & $\begin{array}{c}0.045 \pm \\
0.000\end{array}$ & $\begin{array}{c}0.418 \pm \\
0.002\end{array}$ & $\mathrm{Nd}$ & $\mathrm{Nd}$ & $\mathrm{Nd}$ & $\begin{array}{c}0.009 \pm \\
0.007\end{array}$ & $\mathrm{Nd}$ & $\begin{array}{c}0.032 \pm \\
0.000\end{array}$ \\
\hline $\begin{array}{c}\text { Coffee } \\
\text { Cup }\end{array}$ & $\begin{array}{c}86.092 \pm \\
0.458\end{array}$ & $\begin{array}{c}0.191 \pm \\
0.008\end{array}$ & $\begin{array}{c}0.008 \pm \\
0.003\end{array}$ & $\begin{array}{c}0.271 \pm \\
0.001\end{array}$ & $\begin{array}{c}0.053 \pm \\
0.000\end{array}$ & $\begin{array}{c}1.829 \pm \\
0.173\end{array}$ & $\begin{array}{c}0.214 \pm \\
0.001\end{array}$ & $\begin{array}{c}4.667 \pm \\
0.024\end{array}$ & $\begin{array}{c}0.333 \pm \\
0.001\end{array}$ & $\begin{array}{c}0.078 \pm \\
0.010\end{array}$ & $\begin{array}{c}0.061 \pm \\
0.004\end{array}$ & $\mathrm{Nd}$ & $\mathrm{Nd}$ & $\begin{array}{c}0.404 \pm \\
0.002\end{array}$ \\
\hline $\begin{array}{c}\text { Pastry } \\
\text { Box }\end{array}$ & $\begin{array}{c}13.175 \pm \\
0.107\end{array}$ & $\mathrm{Nd}$ & $\mathrm{Nd}$ & $\begin{array}{c}1.118 \pm \\
0.005\end{array}$ & $\mathrm{Nd}$ & $\begin{array}{c}2.174 \pm \\
0.091\end{array}$ & $\begin{array}{c}0.511 \pm \\
0.002\end{array}$ & $\begin{array}{c}5.046 \pm \\
0.018\end{array}$ & $\begin{array}{c}0.311 \pm \\
0.001\end{array}$ & $\begin{array}{c}0.033 \pm \\
0.004\end{array}$ & $\mathrm{Nd}$ & $\begin{array}{c}0.007 \pm \\
0.007\end{array}$ & $\mathrm{Nd}$ & $\begin{array}{c}0.227 \pm \\
0.000\end{array}$ \\
\hline Sweet Box & $\begin{array}{c}46.644 \pm \\
0.087\end{array}$ & $\begin{array}{c}0.081 \pm \\
0.017\end{array}$ & $\mathrm{Nd}$ & $\begin{array}{c}0.265 \pm \\
0.000\end{array}$ & $\mathrm{Nd}$ & $\begin{array}{c}0.255 \pm \\
0.012\end{array}$ & $\begin{array}{c}0.452 \pm \\
0.002\end{array}$ & $\begin{array}{c}8.704 \pm \\
0.032\end{array}$ & $\begin{array}{c}0.208 \pm \\
0.000\end{array}$ & $\begin{array}{c}0.100 \pm \\
0.000\end{array}$ & $\begin{array}{c}0.232 \pm \\
0.001\end{array}$ & $\mathrm{Nd}$ & $\mathrm{Nd}$ & $\begin{array}{c}0.220 \pm \\
0.001\end{array}$ \\
\hline Pizza Box & $\begin{array}{r}102.722 \\
\pm 0.264\end{array}$ & $\begin{array}{c}0.300 \pm \\
0.024\end{array}$ & $\begin{array}{c}0.015 \pm \\
0.000\end{array}$ & $\begin{array}{c}0.832 \pm \\
0.002\end{array}$ & $\mathrm{Nd}$ & $\begin{array}{c}0.452 \pm \\
0.005\end{array}$ & $\begin{array}{c}0.832 \pm \\
0.002\end{array}$ & $\begin{array}{c}37.209 \pm \\
0.101\end{array}$ & $\begin{array}{c}0.439 \pm \\
0.001\end{array}$ & $\begin{array}{c}0.196 \pm \\
0.004\end{array}$ & $\begin{array}{c}0.339 \pm \\
0.002\end{array}$ & $\begin{array}{c}0.005 \pm \\
0.008\end{array}$ & $\mathrm{Nd}$ & $\begin{array}{c}0.547 \pm \\
0.001\end{array}$ \\
\hline $\begin{array}{c}\text { French } \\
\text { Fries Box }\end{array}$ & $\begin{array}{c}33.950 \pm \\
0.114\end{array}$ & $\begin{array}{c}0.028 \pm \\
0.010\end{array}$ & $\begin{array}{c}0.035 \pm \\
0.000\end{array}$ & $\begin{array}{c}0.289 \pm \\
0.001\end{array}$ & $\mathrm{Nd}$ & $\begin{array}{c}0.092 \pm \\
0.003\end{array}$ & $\begin{array}{c}0.543 \pm \\
0.002\end{array}$ & $\begin{array}{c}7.657 \pm \\
0.029\end{array}$ & $\begin{array}{c}0.285 \pm \\
0.001\end{array}$ & $\begin{array}{c}0.079 \pm \\
0.002\end{array}$ & $\begin{array}{c}0.083 \pm \\
0.003\end{array}$ & $\begin{array}{c}0.004 \pm \\
0.002\end{array}$ & $\mathrm{Nd}$ & $\begin{array}{c}0.152 \pm \\
0.000\end{array}$ \\
\hline Paper Bag & $\begin{array}{c}46.998 \pm \\
0.064\end{array}$ & $\begin{array}{c}0.097 \pm \\
0.018\end{array}$ & $\mathrm{Nd}$ & $\begin{array}{c}0.281 \pm \\
0.000\end{array}$ & $\mathrm{Nd}$ & $\begin{array}{c}0.026 \pm \\
0.001\end{array}$ & $\begin{array}{c}0.328 \pm \\
0.000\end{array}$ & $\begin{array}{c}4.038 \pm \\
0.010\end{array}$ & $\begin{array}{c}0.237 \pm \\
0.000\end{array}$ & $\begin{array}{c}0.095 \pm \\
0.001\end{array}$ & $\begin{array}{c}0.051 \pm \\
0.004\end{array}$ & $\mathrm{Nd}$ & $\begin{array}{c}0.153 \pm \\
0.073\end{array}$ & $\begin{array}{c}0.232 \pm \\
0.000\end{array}$ \\
\hline
\end{tabular}

${ }^{*} \mathrm{Nd}-$ Not detected. 
Co-0.02, Cr-0.250, Cu-4, Fe-40, Ni-0.14, Pb-0.010, and V-0.01 [11]. Few samples contained heavy metals like $\mathrm{Al}, \mathrm{As}, \mathrm{Co}, \mathrm{Cr}, \mathrm{Ni}, \mathrm{Pb}$ and $\mathrm{V}$ in more than the permitted concentration, while all samples contained $\mathrm{Ba}, \mathrm{Cu}, \mathrm{Fe}$, and $\mathrm{Mn}$ within the permitted concentration.

Upto $100 \mathrm{mg} / \mathrm{kg}$ of manganese has been found to be present in wood, which could be the reason for its presence in all the samples that were examined [12]. Manganese toxicity has been observed mostly in the central nervous sytem, although lungs, liver, reproductive, fetal and cardiac toxicity has also been reported [13]. Alumimium is generally used as an electrode in the electrocoagulation process, which is used for decolourization and COD reduction of paper and pulp industry wastewater [14]. Aluminium can potentiate oxidative and inflammatory events, which eventually lead to tissue damage [15]. Chromated Copper Arsenate (CCA) is used as a wood preservative. Arsenic enters the paper and pulp industry if such woods are used as raw materials. Exposure to arsenic results in cutaneous, developmental, hematologic, reproductive, and vascular effects [16]. The main source for vanadium contaminated soil are release of vanadium by anthropogenic activities such as burning of fossil fuels, fertilizer and pesticide application and recycling of domestic waste. When vanadium is present above the tolerable levels, it causes oxidative damage [17].

Over the last two decades, wood preservation scientists have refocused on the use of boron due to its favorable environmental characteristics [18]. Clinical effects of boron toxicity include irritability, seizures and gastrointestinal disturbances [19]. Nickel is present in the form of catalysts and pigments [20]. Nickel is an important human toxicant, as it has the ability to cause carcinoma [21]. Tellurium demonstrates important role in industrial applications. Tellurium toxicity mainly affects kidney, nervous system, skin, and the fetus [22]. Barium sulfate and barium hydroxide play a role in papermaking [23]. The toxic outcomes of barium compounds include cardiac and/ or renal failure, pulmonary edema, respiratory paralysis, and gastric as well as intestinal hemorrhages [24]. The transition metals copper and cobalt are involved in the electrochemical oxidation of paper and pulp mill wastewater [25]. The health effects include a complex clinical syndrome, which mainly includes endocrine, neurological and cardiovascular deficits [26]. Chromium causes a harmful impact on human beings as it is a carcinogenic and mutagenic in nature [27]. Lead and Chromium mainly come from printing inks [28]. Lead is toxic in nature. It causes damage to the kidneys, and various systems like, the cardiovascular, immune, hematopoietic, central nervous and reproductive system [29]. The role of titanium dioxide is that it is the brightest and most effective opacifier used in paper making industry [30]. Titanium dioxide is carcinogenic to human beings [31].

Figure 1 shows the levels of different heavy metals in the food packaging PPB samples.

In this study, all samples contained $\mathrm{Mn}, \mathrm{Cu}$, and $\mathrm{Fe}$ within the permitted concentration. However, the presence of $\mathrm{Mn}, \mathrm{Cu}$ and $\mathrm{Fe}$ ions in the paper and paperboard food packages catalyses the initiation of autoxidation of unsaturated 

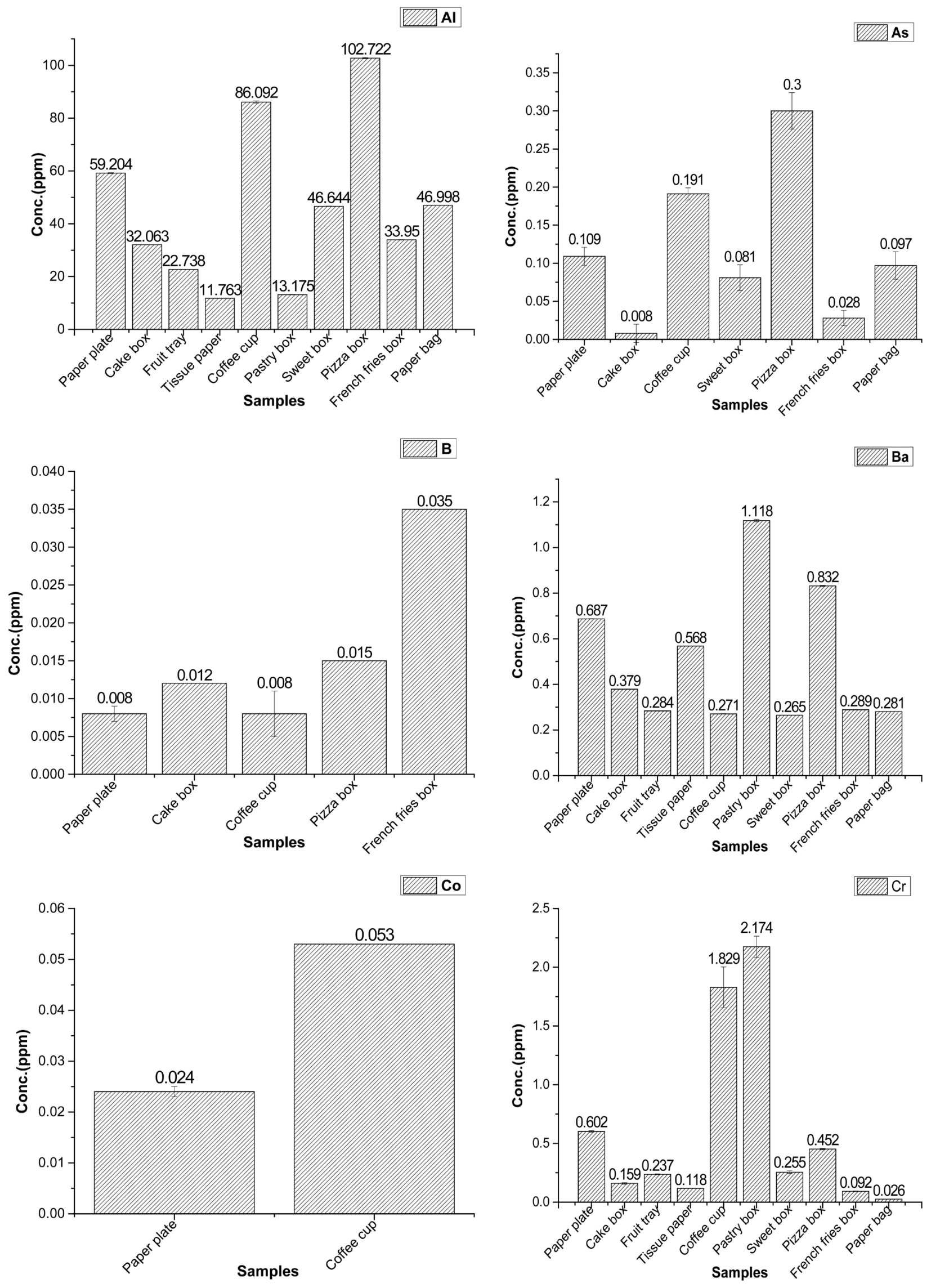

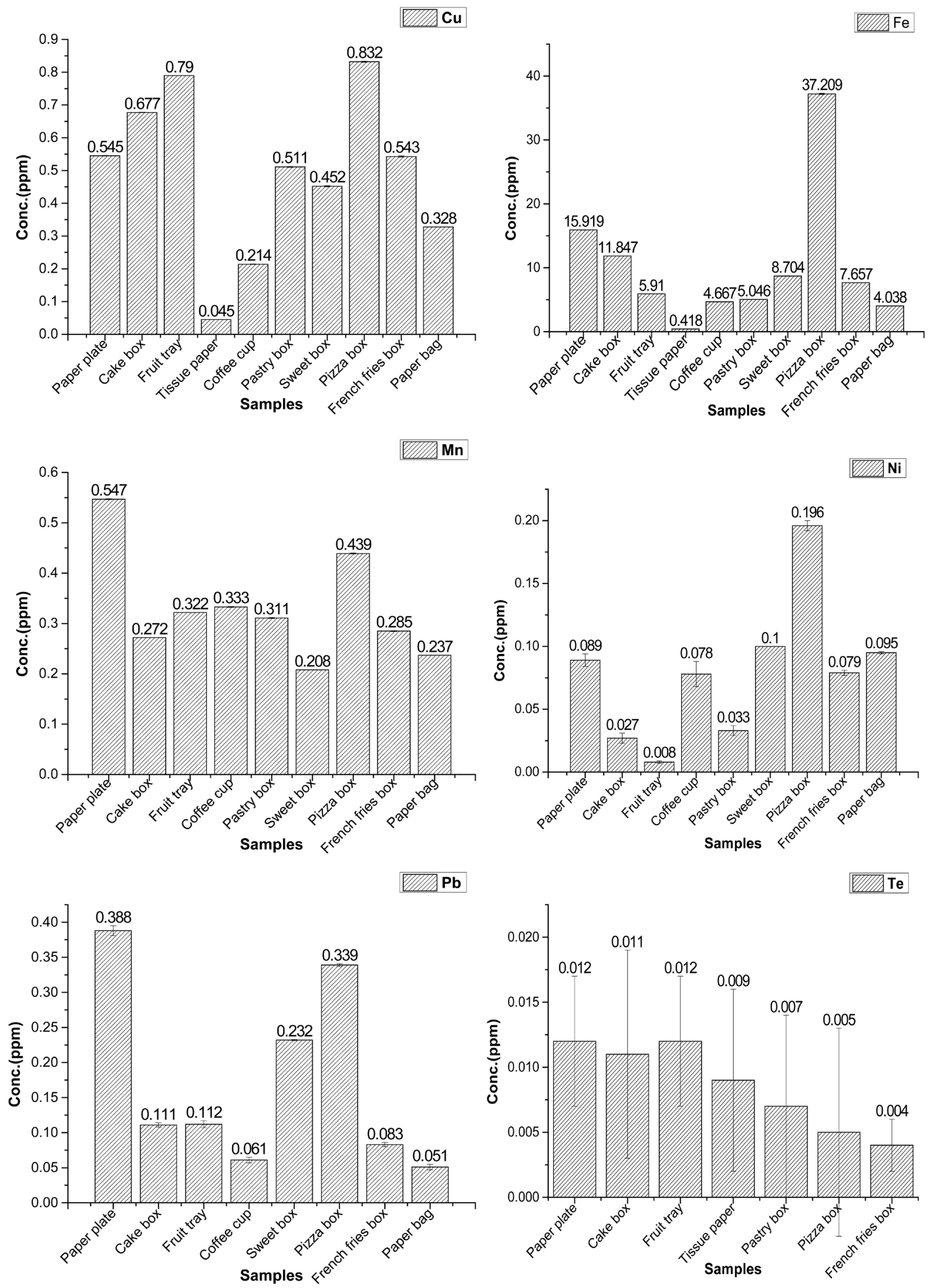

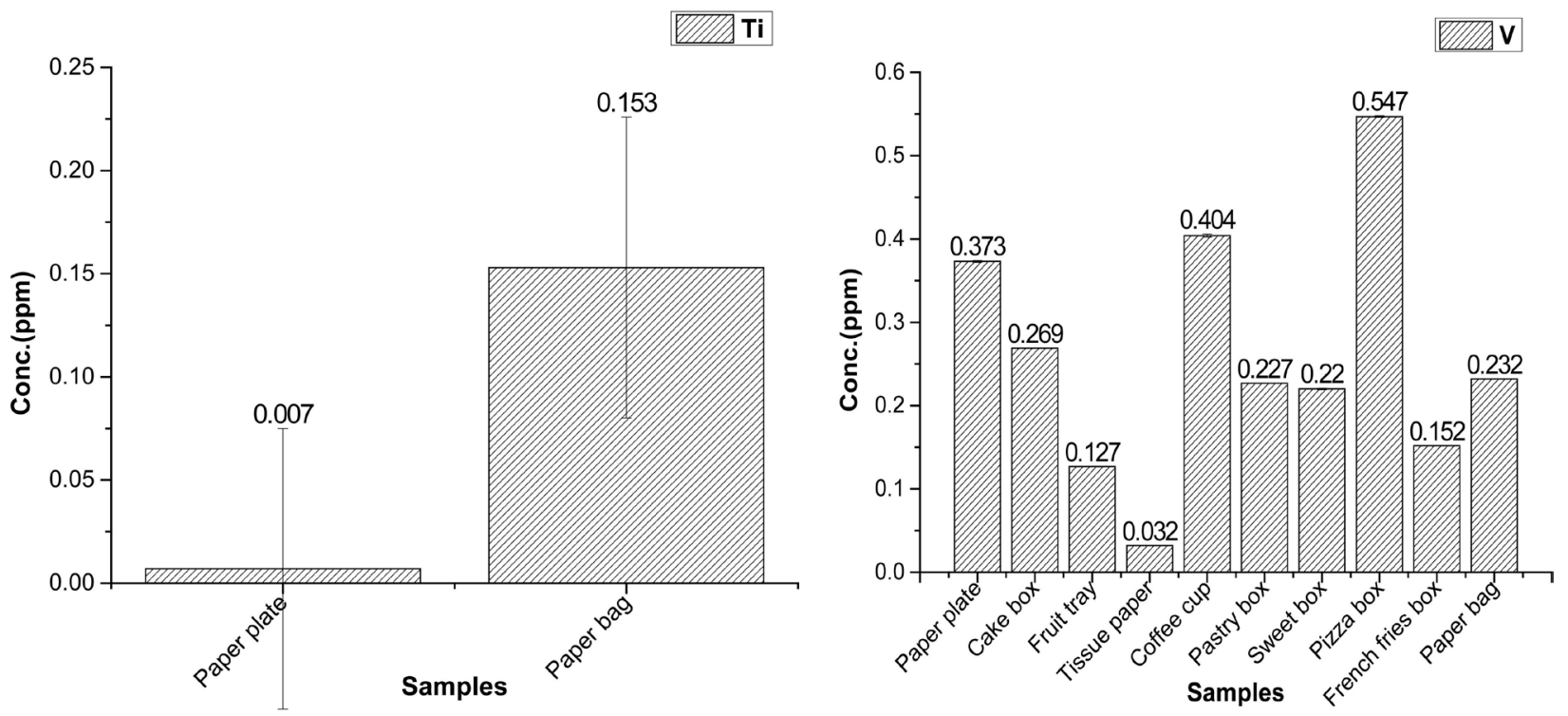

Figure 1. Levels of different heavy metal levels in food packaging PPB samples.

fatty acids leading to the formation of odorous volatile compounds like aldehydes, ketones, and alcohols which brings an unpleasant feeling in the customer and may lead to rejection of food even though the food has been spoiled or not [32].

\section{Conclusion}

In summary, this is a comprehensive research on the occurrence of a wide range of heavy metals in various samples of Indian food packaging PPBs. Comparison of the measured concentrations with permitted standards suggests that the presence of these contaminants may be associated with health hazards. The findings of this study will aid in understanding of the potential risk of rejection of food packages due to odorous compounds generation which is catalyzed by heavy metals. Future studies and regulatory actions should focus on strict monitoring of packaging materials at all stages, starting from raw material selection, storage, paper production, and till it reaches the consumer.

\section{Acknowledgements}

The authors are grateful to Central Instrumentation Facility, IIT Roorkee (SRE Campus) and Ministry of Human Resource Development (MHRD), India; fellowship contingency for carrying out this work.

\section{Conflicts of Interest}

The authors declare no conflicts of interest regarding the publication of this paper.

\section{References}

[1] Ahmadkhaniha, R. and Rastkari, N. (2017) Identification of Suspected Hazardous Chemical Contaminants in Recycled Pastry Packaging. Acta Scientiarum Polono- 
rum Technologia Alimentaria, 16, 33-41.

[2] Mohammadpour, I., Ahmadkhaniha, R., Zare Jeddi, M. and Rastkari, N. (2016) Heavy Metals in Recycled Pastry Packages and Pastries. Acta Alimentaria, 45, 509-514. https://doi.org/10.1556/066.2016.45.4.7

[3] Triantafyllou, V.I., Akrida-Demertzi, K. and Demertzis, P.G. (2007) A Study on the Migration of Organic Pollutants from Recycled Paperboard Packaging Materials to Solid Food Matrices. Food Chemistry, 101, 1759-1768.

https://doi.org/10.1016/j.foodchem.2006.02.023

[4] Conti, M.E. (1997) The Content of Heavy Metals in Food Packaging Paper Boards: An Atomic Absorption Spectroscopy Investigation. Food Research International, 30, 343-348. https://doi.org/10.1016/S0963-9969(97)00062-8

[5] Nerín, C. and Asensio, E. (2007) Migration of Organic Compounds from a Multilayer Plastic-Paper Material Intended for Food Packaging. Analytical and Bioanalytical Chemistry, 389, 589-596. https://doi.org/10.1007/s00216-007-1462-1

[6] Khan, R., Srivastava, R., Abdin, M.Z. and Manzoor, N. (2013) Effect of Soil Contamination with Heavy Metals on Soybean Seed Oil Quality. European Food Research and Technology, 236, 707-714. https://doi.org/10.1007/s00217-013-1926-9

[7] Tangahu, B.V., Abdullah, S., Rozaimah, S., Basri, H., Idris, M., Anuar, N. and Mukhlisin, M. (2011) A Review on Heavy Metals (As, Pb, and Hg) Uptake by Plants through Phytoremediation. International Journal of Chemical Engineering, 2011, Article ID: 939161. https://doi.org/10.1155/2011/939161

[8] Nouri, J., Mahvi, A.H. and Bazrafshan, E. (2010) Application of Electrocoagulation Process in Removal of Zinc and Copper from Aqueous Solutions by Aluminum Electrodes. International Journal of Environmental Research, 4, 201-208.

[9] Kim, K.C., Park, Y.B., Lee, M.J., Kim, J.B., Huh, J.W., Kim, D.H. and Kim, J.C. (2008) Levels of Heavy Metals in Candy Packages and Candies Likely to Be Consumed by Small Children. Food Research International, 41, 411-418. https://doi.org/10.1016/j.foodres.2008.01.004

[10] Wiik, K. and Helle, T. (1998) Problems with Paper Odour-Possible Ways to Solve them. EUCEPA Symposium, Florence, 12-14 October 1998, 307-315.

[11] Cederberg, D.L., Christiansen, M., Ekroth, S., Engman, J., Fabech, B., Guðjónsdóttir, K., Mikkelsen, B., et al. (2015) Food Contact Materials-Metals and Alloys. Vol. 2015522, Nordic Guidance for Authorities, Industry and Trade, Nordic Council of Ministers. https://doi.org/10.6027/TN2015-522

[12] Zasadowski, D., Hedenström, E., Edlund, H. and Norgren, M. (2012) Removal of Lipophilic Extractives and Manganese Ions from Spruce TMP Waters in a Customized Flotation Cell. BioResources, 7, 2376-2392.

https://doi.org/10.15376/biores.7.2.2376-2392

[13] Crossgrove, J. and Zheng, W. (2004) Manganese Toxicity upon Overexposure. NMR in Biomedicine, 17, 544-553. https://doi.org/10.1002/nbm.931

[14] Kalyani, K.P., Balasubramanian, N. and Srinivasakannan, C. (2009) Decolorization and COD Reduction of Paper Industrial Effluent Using Electro-Coagulation. Chemical Engineering Journal, 151, 97-104. https://doi.org/10.1016/j.cej.2009.01.050

[15] Becaria, A., Campbell, A. and Bondy, S.C. (2002) Aluminum as a Toxicant. Toxicology and Industrial Health, 18, 309-320. https://doi.org/10.1191/0748233702th157oa

[16] Hughes, M.F. (2006) Biomarkers of Exposure: A Case Study with Inorganic Arsenic. 
Environmental Health Perspectives, 114, 1790. https://doi.org/10.1289/ehp.9058

[17] Imtiaz, M., Rizwan, M.S., Xiong, S., Li, H., Ashraf, M., Shahzad, S.M., Tu, S., et al. (2015) Vanadium, Recent Advancements and Research Prospects: A Review. Environment International, 80, 79-88. https://doi.org/10.1016/j.envint.2015.03.018

[18] Obanda, D.N., Shupe, T.F. and Barnes, H.M. (2008) Reducing Leaching of Boron-Based Wood Preservatives-A Review of Research. Bioresource Technology, 99, 7312-7322. https://doi.org/10.1016/j.biortech.2007.12.077

[19] Bakirdere, S., Orenay, S. and Korkmaz, M. (2010) Effect of Boron on Human Health. The Open Mineral Processing Journal, 3, 54-59. https://doi.org/10.2174/1874841401003010054

[20] Grandjean, P. (1984) Human Exposure to Nickel. IARC Scientific Publications, No. $53,469-485$.

[21] Macomber, L. and Hausinger, R.P. (2011) Mechanisms of Nickel Toxicity in Microorganisms. Metallomics, 3, 1153-1162. https://doi.org/10.1039/c1mt00063b

[22] Taylor, A. (1996) Biochemistry of Tellurium. Biological Trace Element Research, 55, 231-239. https://doi.org/10.1007/BF02785282

[23] Moffett, D., Smith-Simon, C. and Stevens, Y.W. (2007) Toxicological Profile for Barium and Barium Compounds.

[24] Kravchenko, J., Darrah, T.H., Miller, R.K., Lyerly, H.K. and Vengosh, A. (2014) A Review of the Health Impacts of Barium from Natural and Anthropogenic Exposure. Environmental Geochemistry and Health, 36, 797-814. https://doi.org/10.1007/s10653-014-9622-7

[25] Wang, B., Gu, L. and Ma, H. (2007) Electrochemical Oxidation of Pulp and Paper Making Wastewater Assisted by Transition Metal Modified Kaolin. Journal of Hazardous Materials, 143, 198-205. https://doi.org/10.1016/j.jhazmat.2006.09.013

[26] Leyssens, L., Vinck, B., Van Der Straeten, C., Wuyts, F. and Maes, L. (2017) Cobalt Toxicity in Humans-A Review of the Potential Sources and Systemic Health Effects. Toxicology, 387, 43-56. https://doi.org/10.1016/j.tox.2017.05.015

[27] Skrzydlewska, E., Balcerzak, M. and Vanhaecke, F. (2003) Determination of Chromium, Cadmium and Lead in Food-Packaging Materials by Axial Inductively Coupled Plasma Time-of-Flight Mass Spectrometry. Analytica Chimica Acta, 479, 191-202. https://doi.org/10.1016/S0003-2670(02)01527-1

[28] Xue, M., Wang, S. and Huang, C. (2010) Determination of Heavy Metals (Pb, Cd, $\mathrm{Cr}$ and $\mathrm{Hg}$ ) in Printed Paper as Food Packaging Materials and Analysis of Their Sources. CIESC Journal, 12, 32.

[29] Othman, Z.A.A. (2010) Lead Contamination in Selected Foods from Riyadh City Market and Estimation of the Daily Intake. Molecules, 15, 7482-7497. https://doi.org/10.3390/molecules15107482

[30] Smook, G.A. (1989) Overview of the Pulp and Paper Industry from a Chemical Industry Perspective. Journal of Chemical Technology \& Biotechnology, 45, 15-27. https://doi.org/10.1002/jctb.280450104

[31] Baan, R., Straif, K., Grosse, Y., Secretan, B., El Ghissassi, F. and Cogliano, V. (2006) Carcinogenicity of Carbon Black, Titanium Dioxide, and Talc. The Lancet Oncology, 7, 295-296. https://doi.org/10.1016/S1470-2045(06)70651-9

[32] Wiik, K., Gromsrud, M. and Helle, T. (1998) Studies on Odour Reduction in TCF Bleached Packaging Paper. Journal of Pulp and Paper Science, 24, 291-294. 